\title{
APPLICATION DU SEVRAGE A 12 JOURS DANS L'EXPLOITATION D'UN TROUPEAU PORCIN : RÉSULTATS PRÉLIMINAIRES ET RÉPERCUSSIONS SUR LE NOMBRE ET LE POIDS Des porcelets produts en COMParaison AVEC UN SEVRAGE A 5-6 SEMAINES
}

A. Aumaitre, J. LE PAN, J. Rettagliati, L. BINA et P. ROUSseaU*

\author{
Station de Recherches sur l'Elevage des Porcs, \\ Centre national de Recherches zootechniques, $I . N . R . A$, \\ 78350 Jouy en Josas \\ * Institut technique du Porc, \\ 149, rue de Bercy. \\ 75579 Paris Cedex 12
}

\section{RÉSUMÉ}

Une étude des répercussions techniques et économiques d'un sevrage à IO-I 2 jours par rapport au sevrage fonctionnel à 35-40 jours a été entreprise sur 325 truies appartenant à 5 élevages du département des Côtes du Nord, réparties en deux groupes expérimentaux : 152 sevrés à I 3,4 jours en moyenne et $\mathrm{I} 73$ truies sevrées à 38,8 jours. Les performances sont mesurées et exprimées en moyenne à partir des données enregistrées sur au moins 4 portées successives pour chaque truie. Elles concernent :

- Les effectifs de porcelets par portée, à la naissance, à I2, 42, 63 et 70 jours ;

- Le poids de la portée aux mêmes âges ;

- Les performances de reproduction de la Truie, notamment l'intervalle sevrage-œstrus, sevrage-fécondation, pourcentage de réformes.

Les performances moyennes montrent peu d'influence de la technique utilisée sur les délais entre le sevrage et une nouvelle fécondation : intervalles-sevrage-øestrus, 12,5 et 13,5 jours ; sevrage-fécondation 19,9 et 20,6 pour le sevrage à 12 jours ou a 38 jours. Seul le pourcentage de truies revenues en chaleur moins de 5 jours après le sevrage est significativement plus faible (5 p. IOo) pour une durée de lactation écourtée par rapport au traitement habituel (I 7 p. Ioo). Cependant, la durée entre le sevrage et une nouvelle fécondation varie beaucoup plus suivant la technicité de l'éleveur, les techniques d'élevage utilisées ou le troupeau exploité.

Par ailleurs, ni le pourcentage de retours en chaleur, ni le taux de réforme réel ou recommandé (éliminant les animaux présentant des délais anormaux) ne sont modifiés par un sevrage à I3 jours.

Cependant, bien que les différences ne soient pas significatives, on observe une diminution de la taille de la portée à la naissance et qui se maintient jusqu'à deux mois après un sevrage trop précoce, $(8,08$ contre 8,70 porcelets en moyenne à 2 mois $)$.

Dans nos conditions expérimentales, nous observons une légère diminution (non significative) du poids moyen des porcelets à deux mois dans le cas d'un sevrage très précoce.

Cependant, le sevrage à 13 jours entraîne une augmentation significative du nombre des portées produites par truie et par an $(2,49$ contre 2,10$)$ observée globalement en tenant compte 
de toutes les truies, entraînant une production théorique de Ir à I $4 \mathrm{~kg}$ de porcelets de plus, à deux mois par un sevrage à 13 jours.

Il semble, compte tenu de nos observations, que l'âge de 13 jours constitue un âge minimum au sevrage chez les porcelets.

\title{
SUMMARY
}

\author{
WEANING AT I2 DAYS PRACTISED IN A PIG HERD : \\ PREIIMINARY RESULTS AND REPERCUSSIONS \\ ON THE NUMBER AND WEIGHT OF PIGLETS AS COMPARED \\ TO WEANING AT $5 / 6$ WEEKS
}

The technical and economic repercussions of weaning at Io-I 2 days as compared to usual weaning at 35-40 days were studied in 325 sows belonging to 5 pig production units of the "Côtes du Nord " department. The animals were distributed into two experimental groups : the piglets of 152 sows were weaned at 13.4 days, on an average, and those of 163 sows, at 38.8 days. The performances were measured and expressed as mean values from the data recorded on at least 4 successive litters for each sow.

They concerned :

- Number of piglets per litter at birth, I 2, 42,63 and 70 days;

- Weight of the litter at the same ages ;

- Reproductive performances of the sow, especially the intervals : weaning-œstrus, weaningfertilization and the percentage of culled sows.

The mean performances showed that the technique used only slightly affected the interval between weaning and fertilization : weaning-cestrus, I2.5 days and 13.5 days; weaningfertilization, 19.9 and 20.6 days for weaning at 12 or $3^{8}$ days, respectively. Only the percentage of returns to œestrus recorded less than 5 days after weaning was significantly lower ( 5 p. 100) for a shorter lactation period as compared to usual conditions ( 7 p. Ioo).

However the length of the interval between weaning and first fertilization depended much more on the competence of the pig breeder, the techniques used and the behaviour of the herd.

In addition, neither the percentage of returns to ostrus, nor the real or recommended culling rate (elimination of animals presenting abnormal intervals) were changed by weaning at $\mathrm{I} 3$ days.

However, even though the differences were not significant, we noticed a reduction of the litter size at birth, maintained till 2 months after too early weaning (a mean number of 8.08 versus 8.70 . piglets at 2 months).

Under our experimental conditions, we observed a slight decrease (non significant) in the mean weight of piglets at 2 months after very early weaning.

However, weaning at ${ }_{1} 3$ days led to a significant increase in the number of litters per sow and per year (2.49 versus 2.ro). This observation was made from the total stock of sows and showed an enhancement of the theoretical production of piglets of I I to $14 \mathrm{~kg}$ at the age of 2 months after weaning at $i_{3}$ days.

On account of these observations, it seems that the age of 13 days constitute a minimum weaning age for piglets. 